Poshdar, M., Gonzalez, V.A., Antunes, R., Ghodrati, N., Katebi, M., Valasiuk, S., Alqudah, H., and Talebi, S. (2019). "Diffusion of Lean Construction in Small to Medium-Sized Enterprises of Housing Sector." In: Proc. $27^{\text {th }}$ Annual Conference of the International. Group for Lean Construction (IGLC), Pasquire C. and Hamzeh F.R. (ed.), Dublin, Ireland, pp. 383-392 DOI: https://doi.org/10.24928/2019/0257. Available at: <www.iglc.net>.

\title{
DIFFUSION OF LEAN CONSTRUCTION IN SMALL TO MEDIUM-SIZED ENTERPRISES OF HOUSING SECTOR
}

\author{
Mani Poshdar', Vicente A. Gonzalez ${ }^{2}$, Ricardo Antunes ${ }^{3}$, Nariman Ghodrati ${ }^{4}$, Milad \\ Katebi $^{5}$, Stanislau Valasiuk ${ }^{6}$, Hamzah Alqudah ${ }^{7}$, and Saeed Talebi ${ }^{8}$
}

\begin{abstract}
The construction sector is known for its deficient productivity level compared to other sectors such as manufacturing. Lean approach, however, presents a promising option given its proven ability to improve the performance in other sectors. This study investigates the diffusion level of lean construction among the small to medium size enterprises (SMEs) by conducting a telephone survey in the Auckland region of New Zealand. The survey involved 100 enterprises active in the housing sector. The results indicated the rate of diffusion at three stages of a simplified innovation diffusion model including the knowledge exposure, decision analysis and implementation. The results are attributed to three main elements including the characteristics of SMEs as social units, the time required to attract adopters, and the level and type of communication must be used to reach the potential adopters. The study identified five main questions on the enablers and barriers of diffusion of lean construction to be addressed in future research.
\end{abstract}

\section{KEYWORDS}

Benefits realization, action learning/research, trust, diffusion, SMEs in housing.

\section{INTRODUCTION}

In New Zealand, the construction sector operates near capacity being incapable of attending

Lecturer, Built Envir. Engrg. Dept., Auckland Univ. of Technology, Auckland, New Zealand, mani.poshdar@aut.ac.nz

2 Senior Lecturer, Civil and Envir. Engrg. Dept., Univ. of Auckland, Auckland, New Zealand, v.gonzalez@auckland.ac.nz

3 Civil and Envir. Engrg. Dept., Univ. of Auckland, Auckland, New Zealand, rsan640@ aucklanduni.ac.nz

4 Lecturer, Built Envir. Engrg. Dept., Auckland Univ. of Technology, Auckland, New Zealand, nariman.ghodrati@aut.ac.nz

5 PhD student, Built Envir. Engrg. Dept., Auckland Univ. of Technology, Auckland, New Zealand, milad.katebi@aut.ac.nz

$6 \quad$ Built Envir. Engrg. Dept., Auckland Univ. of Technology, Auckland, New Zealand, sttasv@ gmail.com

7 PhD candidate, Built Envir. Engrg. Dept., Auckland Univ. of Technology, Auckland, New Zealand, hamzah.alqudah@aut.ac.nz

8 Lecturer, School of Art, Design and Architecture, Univ. of Huddersfield, UK, $\underline{\text { S.Talebi@ hud.ac.uk }}$ 
the current demand (Pacifecon N. Z. Itd 2018). Despite such a high demand from the market the industry even shows financial loses (Herald 2018). The construction sector heads as the least productive industry in the country since the $90 \mathrm{~s}$ with no sign of improvement in the past forty years (Curtis 2018). This deficient productivity is combined with other issues notorious to the sector including the failure to attract professionals (Ministry of Business and Employment 2017), poor plan reliability (Harris 2017), and substandard quality (Gordon and Curtis 2018). Lean construction has proven its ability to offer significant improvements in similar circumstances across several areas such as cost structure, job satisfaction, plan reliability, quality, and productivity (Sacks et al. 2010; Gao and Low 2014; O. AlSehaimi et al. 2014; Poshdar 2015). Despite lean construction has shown presence in New Zealand; little is known about its level of acceptance by the small to medium-sized enterprises (SME) that form the skeleton of the country's construction industry (Fida 2008).

This study intended to find out and elaborate on the state of diffusion of lean construction among SMEs active in the Auckland region of New Zealand. The city has been forecasted to deliver $41 \%$ of all building and construction activity of the country from 2017 to the end of 2022 (Ministry of Business, Innovation and Employment (MBIE) 2017). The results provide a clear image of the dissemination of lean construction among SMEs, which enables initiate and design actions to increase lean adoption.

\section{SMES AND LEAN CONSTRUCTION: A LITERATURE REVIEW}

The importance of SMEs is well identified worldwide because of their significant contributions to satisfying various socio-economic objectives, such as higher growth of employment, output, promotion of exports and fostering entrepreneurship (Singh 2011). Despite the consensus on the importance of SMEs, no universal agreement exists about their size in particular. This study adheres to the definition provided by New Zealand Statistics, where SMEs are defined as a unit that consists of between 0 to 49 full-time employees. These enterprises make $95 \%$ of companies in the global market, which produce more than 50\% of the economic value (Fida 2008). In Organisation for Economic Cooperation Development (2017) countries, SMEs account for $99 \%$ of all enterprises and contribute to $70 \%$ of jobs on average.

In construction, the majority of the active companies are from the SMEs category. According to New Zealand Statistics, SMEs constitute $76 \%$ of the active companies that employ about $68 \%$ of the total workforce in the industry (New Zealand Statistics 2018). A majority of SMEs involve in the housing sector (Ghodrati et al. 2018). In New Zealand, this sector accounted for almost $70 \%$ of the construction value (Ministry of Business, Innovation and Employment (MBIE) 2017). The significance of SMEs in the construction industry is increasing, especially in developed countries, where large companies (generally main contractors) tend to outsource construction activities (Farmer 2016). The restricted size of SMEs, however, imposes a significant limitation on their abilities to access financial and human resources (Egbelakin et al. 2018; Ghodrati et al. 2018). SMEs are also known as being typically owner-operated. In this structure, the management and operational layers 
merge to create a simple organizational structure (Alquda et al. 2018). In general, managers in SMEs are more independent; use multitasking, highly personalized, and operate in a particular area (New Zealand Government 2006; Darcy et al. 2014; Inan and Bititci 2015; Ghodrati et al. 2018; Tezel et al. 2018; Yadav et al. 2019). It gives SMEs unique characteristics that are put in contrast to those of large enterprises in Table 1.

Table 1: Large versus small to medium size enterprises (SMEs)

\begin{tabular}{|c|c|c|}
\hline Attribute & Large & SME \\
\hline $\begin{array}{l}\text { Organizational } \\
\text { Structure }\end{array}$ & $\begin{array}{c}\text { Hierarchical with several layers of } \\
\text { management }\end{array}$ & Flat with few layers of management \\
\hline Leadership & Involves strategic activities & Involves operational activities \\
\hline $\begin{array}{l}\text { Management } \\
\text { Style }\end{array}$ & Participative & $\begin{array}{l}\text { Empowered supervision that } \\
\text { commands and controls }\end{array}$ \\
\hline $\begin{array}{l}\text { Operational } \\
\text { Improvement }\end{array}$ & $\begin{array}{l}\text { Is often introduced with a holistic } \\
\text { perspective }\end{array}$ & $\begin{array}{l}\text { Is introduced with a partial and } \\
\text { fragmentary prospect }\end{array}$ \\
\hline $\begin{array}{l}\text { Human } \\
\text { Resource }\end{array}$ & $\begin{array}{l}\text { Involves continuous training and staff } \\
\text { development }\end{array}$ & $\begin{array}{l}\text { Training and staff development is } \\
\text { ad-hoc }\end{array}$ \\
\hline $\begin{array}{l}\text { Networking } \\
\text { approach }\end{array}$ & $\begin{array}{l}\text { Extensive and structured external } \\
\text { networking }\end{array}$ & $\begin{array}{l}\text { Limited and unstructured external } \\
\text { networking }\end{array}$ \\
\hline Innovation & Derived by $R \& D$ & Derived by clusters and networking \\
\hline
\end{tabular}

The simple organizational structure and the flexible production process of SMEs provide a unique ability to implement lean construction. The increasing presence and the number of SMEs involved in the construction sector highlight the imminent need for understanding the issues around the diffusion of lean construction to SMEs.

\section{AN INNOVATION DIFFUSION MODEL}

Lean construction strives for a new delivery system that can be applied to any construction development with a particular focus on the complex, uncertain, and quick types of projects (Howell 1999). It fits well into the definition of innovation that refers to a new invention, tool, system or approach intending to change an existing situation, providing an enhanced solution to a problem, and improving the overall performance of the product (Hoffmann et al. 2007; Rogers 2010). Therefore, when the users adopt lean construction as their project delivery system, they are anticipated to pass through the stages drew on the diffusion of innovation theory. The theory has been developed by Rogers (1962) to explain how a new product gains momentum and spreads over time in society. This study divided the process into the three main following steps (Figure 1): 


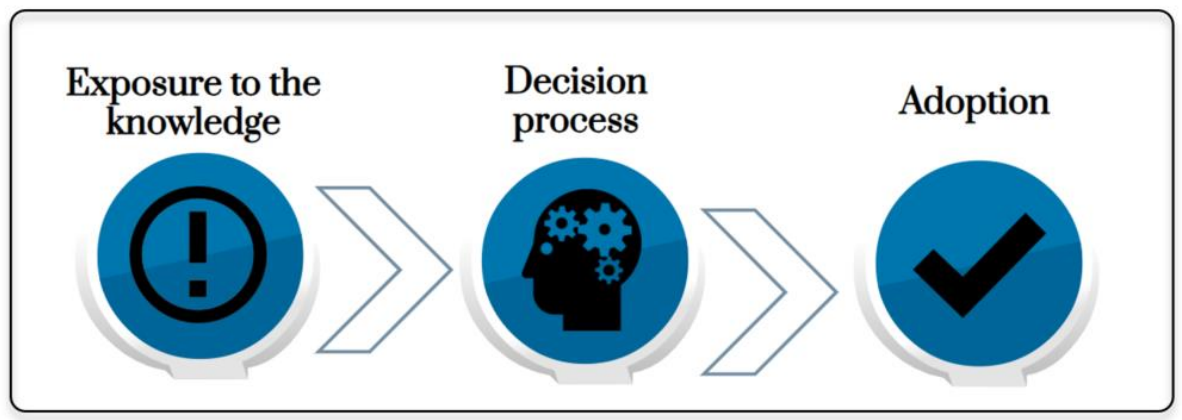

Figure 1: A simplified diffusion model

1) Exposure to the knowledge - users become aware of the existence of the innovation, with restricted knowledge about the details. It commences when the users become exposed to the initial information about the novelty (Rogers 2010). They may find this information in a passive behavior and by an accidental exposure (Coleman et al. 1957), or when a dissatisfaction creates a need, and the users develop a tendency towards self-exposure (Hassinger 1959). Accordingly, the types of knowledge transferred in this step include awareness- knowledge, where the user finds out about the existence of the innovation; how-to knowledge, where the user gets the information necessary to use the innovation properly; and principles knowledge, where the user deals with the functioning principles underlying the way the innovation works (Rogers 2010).

2) Decision process - the users form a favorable or unfavorable attitude towards the innovation (persuasion) and may engage in activities that lead to adopt or reject the innovation. At the persuasion stage, the users become more psychologically involved with the innovation; therefore they actively seek information about the new idea. This information involves relative advantage, compatibility, and complexity associated with the idea. The new information leads to developing a general perception about innovation. In most cases, the users put the innovation on trial on a small scale before making their final decision about adopting or rejecting the novelty (Rogers 2010; Berry and Berry 2018).

3) Adoption - The users put the innovation into use on a large scale and confirm the innovation in the face of conflicting messages arise during implementation. The user may face some problems in the operation when the innovation is implemented. The move from the decision process to the adoption step involves a shift from a mental process to practical behavior. Innovation can be institutionalized and routinized into the ongoing practice if it could pass this last stage successfully (Rogers et al. 2009; Rogers 2010).

\section{RESEARCH METHOD}

The research was designed based on a post-positivism methodology. Accordingly, a quantitative approach was undertaken to obtain an interpretation of diffusion of lean construction to SMEs in Auckland, New Zealand concerning the simplified diffusion model in Figure 1. A telephone survey method enabled the researchers to maintain an 
immediate interaction with the respondents, and quick data processing and handling at later stages. This method also provided a high level of anonymity for the respondents, who wished to hold their opinions in confidentiality. It could facilitate accuracy in responses.

\section{SAMPLE SELECTION}

The study used cluster sampling practice, in which seven residential construction sites were selected as the indicative clusters of construction companies working in the Auckland region. A simple random technique was applied to take two of the construction sites to the further stages of the study. The full list of the subcontractors working within the two selected clusters was obtained from the site managers. The list included the name of companies, type of work they were performing, their phone number, and the contact person. A few information was missing from the list that was retrieved from the internet.

\section{SAMPLE SIZE AND THE RESPONSE RATE}

One hundred and thirty companies were listed from the two clusters used for the sampling purpose. The survey was stopped as soon as 100 responses were collected. This size was obtained based on the guidelines provided by Creswell (2014) called data analysis spiral. It suggests an inductive process in several rounds during which the data are organized, conceptually reviewed, classified and synthesized.

\section{Data Collection}

The data were collected between May and August 2018. Since the telephone survey could interrupt the personal time of the respondents, the interview sessions were designed to take no longer than 10 minutes.

The respondents were requested to answer the following three questions:

1. Please, indicate the size of your company.

2. Has your company ever faced/ been involved with the lean construction topic at any level?

3. Has your company ever practised the use of lean construction in any of its projects?

The first question ensured that the surveyed company is within an SME category. The next two questions investigated the position of the company in relation to the simplified diffusion model (Figure 1).

\section{DISCUSSIONS}

\section{THE ANALYSIS OF THE RESPONDENTS' PROFILE}

The profile of the respondents was studied based on the frequency of the type of work they were delivering in the projects in order to demonstrate the demographics of the sample studied. They were found to be involved in a broad range of works with a relative balance in the frequency observed. Nine activities recorded with a frequency between $4 \%$ top $11 \%$. Figure 2 provides a summary of these activities along with their observed frequency. In this figure, the responses with a rate of fewer than $4 \%$ were grouped as the other. These responses included activities such as surveying, scaffolding, stair construction, membrane 
installation, and waterproofing.

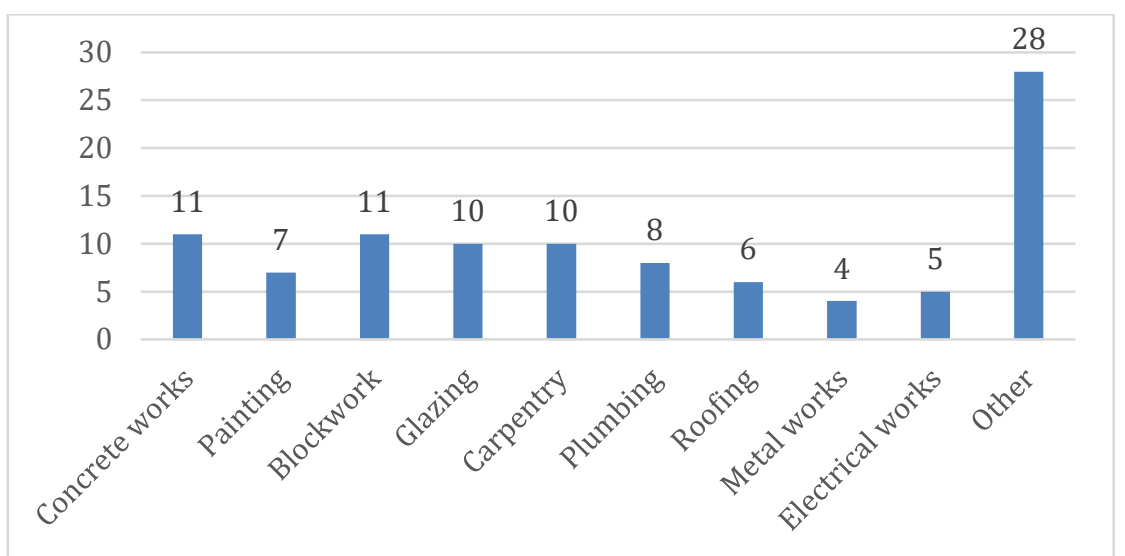

Figure 2: The type of works and the observed frequency

\section{THE KNOWLEDGE AND IMPLEMENTATION LEVELS OBSERVED}

Twenty companies (20\%) identified that they had been exposed to the lean construction idea at some points in their past. Three companies (3\%) were actively using lean construction system. Also, one company (1\%) had used the lean construction system in the past with a discontinuation decision. They associated this decision with the fundamental changes that occurred in the company's managerial team and strategy. Given the differences between the observed rates for the companies with exposure to the lean construction idea and those were implementing the system, the simplified diffusion model (Figure 1) showed a 17\% drop in the decision process step.

\section{COMMENTARY ON THE PATTERN OBSERVED}

We discuss three main elements that can affect the observed pattern in the diffusion level of lean construction among SMEs based on a comparative synthesis of the body of knowledge developed in other fields of science:

\section{THE CHARACTERISTICS OF SMES AS THE SOCIAL UNIT}

A typical construction project can represent a social system comprising of a set of interrelated SME units. This system is known for its cultural resistance to change (Sadler 2011). Such a system often uses patterned arrangements of the units as its primary structure, e.g. the nine common types of works observed in this study represent a recurring pattern that gives stability and regularity to the projects. This arrangement affects the social and communication structure of these individual units that may facilitate or impede the diffusion of lean construction as an innovation in the main system.

\section{System norms}

Norms refer to the behavior patterns established in the units of the social system (Rogers 2010). In construction, SMEs are typically structured around a fragmented work delivery, which can even cause clashes in defining their priorities (Abdullah et al. 2009) and escalating their lack of cooperation (Mossman 2009). They are also known for their meagre 
budget for subcontracting (Bashir et al. 2010), lack of skill, development ignorance, and computer illiteracy (Abdullah et al. 2009; Poshdar et al. 2018). The literature to date also indicates a tendency to use traditional management (Abdullah et al. 2009), lack of commitment, lack of ability to work in a group, lack of self-criticism, weak communication and transparency as other attributes ongoing in construction (Mossman 2009).

\section{COMMUNICATION}

Communication plays a significant role in the diffusion process of innovation (Rogers et al. 2009). The potential users confront two types of uncertainty facing an innovation: the first type relates to the suitability of the innovation to their requirements and the other type concerns about the consequences expected from implementing the innovation. Both types can be reduced by proper communication. The reduction in the uncertainty about the suitability of the innovation will impel the users to exert effort in order to learn about the innovation (Rogers 2010). It will sustain the persuasion phase in the decision making the process (Figure 1). To do so, Lean construction needs to clarify the following three main points to SMEs: What is lean construction? How does it work? And why does it work? In order to reduce the uncertainty about the consequences, the communications should involve innovation-evaluation information (Rogers 2010). It entails answering an inevitable question: What will be the advantages and disadvantages of implementing the innovation in the particular situation of the user?

\section{The opinion leaders and change agents}

Certain individuals play different roles in social systems when communicating the suitability and the implementation consequences of innovation. Opinion leaders serve as the group of individuals who can influence the attitudes of others informally in a desired way with relative frequency (Rogers 2010). In SMEs, the managers can play this role, given their importance in defining the strategic orientation of the enterprise. The literature, however, demonstrates a lack of commitment and support from the top managers (Bashir et al. 2010), coupled with the lack of training and experience for other members, which disrupt a change in the mindsets (Mossman 2009).

In such situations, the presence of a change agent may help to direct the decision process of the enterprise towards the desired orientation. A change agent, however, is typically more competent than his clients technically. It can pose a severe problem in the effectiveness of communicating lean construction as an innovation. As a principle of human communication, the degree to which pairs of individuals who interact are similar in certain attributes, such as beliefs, education, and social status represents the main factor in facilitating the transfer of the ideas. A heterophilous pairs of the change agent and the potential user can effectively interact if they could build a level of empathy (Rogers 2010).

\section{The channels}

A communication channel is a way by which messages are passed from one individual to another. The transfer can take place using the mass media, social media, or interpersonal channels.

The results of various diffusion investigations, however, show that most people depend upon a subjective evaluation conveyed to them from other similar individuals who have 
previously adopted the innovation (Rogers 2010). This dependence on the communicated experience of near-peers suggests that the interpersonal channels can significantly partake in the persuasion and confirmation phases of diffusion.

\section{TIME AND THE ADOPTION RATE}

A cumulative frequency over time plot of the number of adopters typically forms an Sshaped curve (Rogers 2010). It starts with a few adopters known as the innovators; followed by a climb in the number of adopters (involved with the early adopters and the early majority, respectively). Afterwards, the trajectory of the rate begins to level off, as the late majority adopt. Finally, the S-shaped curve reaches its asymptote, when laggards decide to enter into the adoption phase. The results of this study indicate that the lean construction idea has found its early adopters among SMEs, and needs to make sure about engaging the early majority type of adopters in the near future.

\section{CONCLUSION}

This paper studied the state of diffusion of the lean construction system as an innovation among SMEs which are known as the backbone of the construction industry in the majority of the countries. It was found that while $20 \%$ of the companies had been exposed to the knowledge about lean construction, only 3\% were actively using this system. It was discussed that a strong link could be spotted between the level of involvement demonstrated by the SMEs as the social units of the projects and their cultural norms. The norm is formed around the current practices that arrange the units in a fixed pattern in projects to gain stability and regularity. It poses a significant impediment to their extensive involvement in adopting lean construction. To break this pattern, an in-depth understanding of the decision mechanism that drives changes in an SME seems to be necessary. It entails identifying effective people to be targeted and the communication channels to be established with the organization. The paper also classified time as one of the main players in getting the changes ongoing and increasing the rate of the adopters. In the light of the findings a number of research questions can be established: (1) What are the roles of different actors within the construction industry to leverage the introduction of Lean Construction as a disruptive innovation within the SME sector in construction?; (2) What are the reasons for the observed drop between the rate of the SMEs that were exposed to the lean construction knowledge and those are implementing it?; (3) Are there other innovation initiatives that faced similar patterns of the innovation-decision process?; (4) What are the likely drivers of innovation that can optimize the innovation-decision of Lean Construction within the SME sector in construction?; (5) What are the roles of innovators such as universities, professional bodies, industry champions, government to promote Lean Construction within the SMEs sector in construction?

The next step of the research will conduct another round of data collection regarding the lean diffusion state among SMEs. It will involve questions to enhance our understanding of the lean practices in SMEs and to clarify the current state of the three main elements of the diffusion model within these enterprises. An analysis of the responses can support answering the main questions about the drivers of lean diffusion. 


\section{REFERENCES}

Abdullah, S., Abdul-Razak, A., A.Abubakar, and Mohammad, I. S. (2009). "Towards producing best practice in the Malaysian construction industry: the barriers in implementing the Lean Construction Approach." Faulty of Engineering and Geoinformation science, Universiti Teknologi, Malaysia.

Alquda, H., Poshdar, M., Rotimi, J. O., and Oyewobi, L. O. "Determinants of construction organisations' performance: a systematic literature review." Proc., 42nd Australian Universities Building Education Association (AUBEA).

Bashir, A. M., Suresh, S., Proverbs, D. G., and Gameson, R. (2010). "Barriers towards the sustainable implementation of lean construction in the United Kingdom construction organisations." In ARCOM doctoral workshop, pg 1.

Berry, F. S., and Berry, W. D. (2018). "Innovation and Diusion Models in Policy Research." Theories of the policy process, Routledge, 263-308.

Coleman, J., Katz, E., and Menzel, H. (1957). "The diffusion of an innovation among physicians." Sociometry, 20(4), 253-270.

Creswell, J. W. (2014). A concise introduction to mixed methods research, Sage Publications.

Curtis, M. (2018). "Productivity in the Construction Industry 2017." 26-26.

Darcy, C., Hill, J., McCabe, T., and McGovern, P. (2014). "A consideration of organisational sustainability in the SME context: A resource-based view and composite model." European Journal of Training and Development, 38(5), 398-414.

Egbelakin, T., Poshdar, M., Walsh, K. Q., Ingham, J., Johnston, D., Becker, J., Mbachu, J., and Rasheed, E. (2018). "Preparedness of small to medium-sized enterprises to earthquake disaster: Napier and Dunedin case studies." Bulletin of the New Zealand Society for Earthquake Engineering, 51(4).

Farmer, M. (2016). "The farmer review of the UK construction labour model." Construction Leadership Council.

Fida, B. (2008). "The Role of Small and Medium Enterprises (SMEs) in Economic Development." Enterprise Development, Free Online Library.

Gao, S., and Low, S. P. (2014). "The Toyota Way model: an alternative framework for lean construction." Total Quality Management \& Business Excellence, 25(5-6), 664-682.

Ghodrati, N., Yiu, T. W., Wilkinson, S., and Shahbazpour, M. (2018). "A new approach to predict safety outcomes in the construction industry." Safety science, 109, 86-94.

Gordon, G., and Curtis, M. (2018). "Building-quality issues : A literature review."

Harris, C. (2017). "Poor project management blamed for construction budget blowouts."

Hassinger, E. (1959). "Stages in the adoption process." Rural sociology, 24(1), 52.

Herald, N. Z. (2018). "Construction industry in urgent meeting with government ministers over sector problems."

Hoffmann, V., Probst, K., and Christinck, A. (2007). "Farmers and researchers: How can collaborative advantages be created in participatory research and technology development?" Agriculture and human values, 24(3), 355-368.

Howell, G. A. (1999). "What is lean construction." Proc., 7th Ann. Conf. of the Int'l. Group for Lean Construction.

Inan, G. G., and Bititci, U. S. (2015). "Understanding organizational capabilities and 
dynamic capabilities in the context of micro enterprises: a research agenda." ProcediaSocial and Behavioral Sciences, 210, 310-319.

Ministry of Business, I., and Employment (2017). "Future demand for construction workers."

Ministry of Business, Innovation and Employment (MBIE) (2017). "National construction pipeline report 2017." Ministry of Business, Innovation and Employment, Wellington, New Zealand.

Mossman, A. (2009). "Why isn't the UK construction industry going lean with gusto?" Lean Construction Journal.

New Zealand Government (2006). Small and Medium Businesses in New Zealand: Report of the Small Business Advisory Group, Small Business Advisory Group.

New Zealand Statistics (2018). "New Zealand Business Demography Statistics: At February 2017." Retrieved.

O. AlSehaimi, A., Tzortzopoulos Fazenda, P., and Koskela, L. (2014). "Improving construction management practice with the Last Planner System: a case study." Engineering, Construction and Architectural Management, 21(1), 51-64.

Organisation for Economic Co-operation Development "Enhancing the Contributions of SMEs in a Global and Digitalised Economy." Proc., Meeting of the OECD Council at Ministerial Level, Paris, 2017.

Pacifecon N. Z. Itd (2018). "Guide to the National Construction Pipeline Report."

Poshdar, M. (2015). "An Advanced Framework to Manage Uncertainty and Buffers in Construction." PhD, The University of Auckland, The University of Auckland.

Poshdar, M., Gonzalez, V. A., and Kasiviswanathan, B. (2018). "Buffer Management in Construction - A New Zealand Study." 26th Annual Conference of the International. Group for Lean Construction (IGLC), V. A. Gonzalez, ed.Chennai, India, 818-828.

Rogers, E. (1962). "Diffusion of innovations. New York: Free Press."

Rogers, E., Singhal, A., and Quinlan, M. (2009). "Diffusion of Innovations." An Integrated Approach to Communication Theory and Research, D. Stacks, and M. Salwen, eds., Routledge, NY, 418-434.

Rogers, E. M. (2010). Diffusion of innovations, Simon and Schuster.

Sacks, R., Radosavljevic, M., and Barak, R. (2010). "Requirements for building information modeling based lean production management systems for construction." Automation in construction, 19(5), 641-655.

Sadler, L. (2011). "The adaptation and implementation of lean production in the New Zealand construction industry."

Singh, R. K. (2011). "Developing the framework for coordination in supply chain of SMEs." Business Process Management Journal, 17(4), 619-638.

Tezel, A., Koskela, L., and Aziz, Z. (2018). "Current condition and future directions for lean construction in highways projects: A small and medium-sized enterprises (SMEs) perspective." International Journal of project management, 36(2), 267-286.

Yadav, V., Jain, R., Mittal, M. L., Panwar, A., and Sharma, M. K. (2019). "An appraisal on barriers to implement lean in SMEs." Journal of Manufacturing Technology Management, 30(1), 195-212. 